\title{
EMERGENCE OF INTEGRATED MARKETING COMMUNICATIONS AS AN IMPACTFUL TOOL IN SHIFTING CONSUMER BEHAVIOR
}

\author{
Karan Raghani ${ }^{1}$ \\ ${ }^{1}$ Symbiosis Institute of Business Management, Bengaluru
}

\begin{abstract}
The world of business has always been dynamic and fast-paced to the whims of the changing environment and one such aspect of marketing under its huge umbrella - Integrated Marketing Communications is witnessing the boom through the evolution and dynamic changes that the industry is facing with the rise in platforms, mediums, content consumption, new techniques, artificial intelligence, gamification etc. It has evolved with time and has helped businesses to carve new strategies and helped them grow. It has changed the perspectives and broadened the horizons of a consumer's mind by successfully reaching the masses and influencing their decisions. In this paper, we would be tracing whether the emergence of Integrated Marketing Communications as a tool has impacted a buyer's mind and whether it has been proved successful in shifting the consumer behavior.
\end{abstract}

Keyword: Integrated Marketing, Communications, Sales promotion, Consumer behavior, Media, Strategy, Buying behavior, Advertising, Social Media

\section{Introduction}

Since years we have seen the evolution of advertising methods and how the umbrella of marketing and advertising has broadened all this while. Right from the billboard being an immeasurable form of communication for masses to an image banner on Jio Saavn for 'four more shots please' where you can measure all your traffic and leads, we have come a long way. With other factors being an aid to this evolution, such as increased internet penetration, digital adaptiveness among the millennials and the realization of the need for the local content. Now, many businesses - Big and Small are coming ahead with their proposals to the agencies wherein they don't want a particular medium for advertising themselves, they want a 360-degree

approach wherein right from a print advertisement to an email to the client they want everything to hit the bull's eye. Before, the forms of advertisement were very few and expensive, now that the bouquet has added so many flowers to it, advertising has become less expensive in some forms and the businesses of all forms are coming ahead with their wish to advertise themselves on certain platforms. Today, it is not limited to big brands as it was used to, even unconventional businesses and B2B firms are advertising on modern platforms too. In the situation like that of current economy, where competition is fierce and the aim of every business is to win the new customer segments or retain the existing ones through innovative methods and use of right kind of technology. In such a scenario, the efforts of the marketing team by executing new ways of communicating and bidding turns out to be the best way for the success of the business. Hence, considered to be the most reliable source of marketing, integrated marketing communications successfully grabs the attention of buyers as well as providers especially when they rely on multiple mediums for information which affects their purchase decisions. The reason integrated marketing communications is considered to be the most liable tool is because it is used as an approach to planning communications for your business (Big or small) and gives it the caliber to get higher outcomes and aims at diminishing the marketing costs. As relying on individual marketing techniques can cost more than usual like a print ad campaign. It helps in creative consistency throughout channels and helps in tackling the modern business problems in an innovative yet a cost-effective manner. By combining multiple channels like advertising, E-mail and newsletters, social media, telemarketing and right sales promotion, the integrated communication creates a significant impact and that is why its application is gradually increasing. (Linton, 2019) One more reason for this progress is adaption of agencies in creating ads and content in local languages. For e.g.: Finolex- pipes has 6 different websites in 6 different languages which has helped them a lot in increasing their sales in the southern part of India. The ease and adaption of the local content has increased the demand for advertising even in the remote parts of India. After china, India is the $2^{\text {nd }}$ largest smartphone market in the world, which is one of the reasons wherein we see the increased traffic on websites and social media. One more aspect which has made the need for IMC more important is increase in the number of platforms and thereby, increasing the scope of Ad spends for better targeting and segmentation. For e.g.: For generating leads on a premium product, LinkedIn Ads is a better platform as it helps in detailed targeting for CXOs and premium customers. Similarly, there are different platforms suitable for different segments of customers and along with these platforms many traditional businesses don't want to forego their old means of advertising such as pamphlets, brochures, cards etc. The approach of following Integrated communications has been 
prove

$\mathrm{d}$ favorable because it clubs all the possible solutions from different mediums which ultimately aim bringing out the same message across and incorporates a win-win situation and reaches to all relevant stakeholders. Integrated marketing has existed since years but today, it is more important than ever because the audience today is segregated into different channels and covering them all with more possibility is actually possible through integrated approach of communications. Such approaches when used properly yield a great result as one cohesive message across all the channels is targeted toward the audience likewise. (Lake, 2019)

\section{REVIEW OF LITERATURE}

India is one of the favorite markets on the globe. The increasing purchasing power of the Indian economy is an added incentive that drives growth. And in the current age, marketing communication is the dissemination of messages delivered in different forms and different ways. It is very important to determine the current way to deliver the right message to the right customer in the right form. (Burnet, Moriarty, 2001). Streamlining the basic concepts of the promotion will provide an opportunity to talk about their system, in which companies are beginning to actively use the information collected about potential customers, trying to tailor communications to their current needs, that is, to prepare communications to order. (Oleg V. Pavenkov, 2019). The competitive advantage of firms that have brands with high equity includes price premiums, increased customer demand, brands that can be extended easily, more readily accepted communications, better trade leverage, and less vulnerability to competitive marketing activity. Previous researches on IMC have focused on aspects such as its impacts on brand equity and trial effects (Rubtcova, 2019) or on Use and Preferences of Promotional Tools by Small and Micro Business Organizations (Mulchandji Sen, 2017) The previous researches have also emphasized upon the emergence of integrated marketing communications (IMC) that has predominantly influenced thinking and acting among all types of businesses and organizations going through the phases of competition in the present open economy. (Telrandhe, 2010)

The increased competition has made it significant to find ways to retain the customers and increase their brand loyalty. Brand loyalty pre-dominantly contributes to high margin of profits as it increases the chances of re-purchase, decreasing price sensitivity and more optimistic word of mouth promotions and less chances of switching intension. As per the previous researches conducted the term brand loyalty has been associated with behavioral loyalty which revolves around the action of repeat purchasing of a product or service. But many authors have argued and supported the existence of attitudinal loyalty which is associated with customer's preference, his/her attitude towards the brand and product, commitment, intentions, re-purchase cycle etc. which in-turn result into recommendations and positive word of mouth. Some researchers also state that many changes have took place in the concept and form of IMC in the recent years since the way of influencing customer to make the purchase has evolved over time. This includes introduction of Influencer marketing, use of database technology to leverage and expand the customer base, re- marketing strategies, digital marketing etc. The existing researches have worked on the conceptual model which connects the linkage between advertising and sales promotion and the combined effort's impact on consumer intention to switch brands. (Quach, 2016).

As per an article, the role and purpose of advertising hasn't changed and it has always been to sell more of a product or a service at a higher price that a consumer is willing to pay which he won't in the absence of advertisements. The researchers believe that it is not the purpose that has changed but mainly the methods and forms have changed and they have also questioned the effectiveness of these new forms of advertising and if they are even certain. They believe that the purpose of social media is undefined and advertising on social media has lessened the power of persuasion, they also believe that it is the language of advertising that been completely changed into terms which revolved around similar meanings and they discourage the persuasion and have changed the meaning of advertising umbrella. Terms such as 'brand building', 'engaging' and 'relating' to consumers are flipped around without any of the listeners possibly having the same referent as the speaker. It emphasized on the motive that the academic practitioners are using the 'new advertising' as an excuse and have been trying to redefine the conventional notions of advertising by covering it in new terminologies. (Percy, 2012).

A transformational feature of integrated marketing is the shift from the conventional marketing types to become inclusive of all the mediums like public relations, specialty items, merchandising, packaging, licensing etc. and also two-way mediums like events and sponsorship, exhibitions, ecommerce, customer loyalty programs etc. The research also examined that the future scope of integrated marketing is only widening because of factors like mergers and acquisitions of communication

agencies, the need for marketers to develop faster response systems, the desire of businesses to reach out to all their stakeholders collectively yet impactfully etc. In general, IMC is not simple in its implementation but the previous researches emphasize that some businesses find it easier to implement than others. It is said that small, consumer-oriented, and service-focused in sectors like agriculture, mining, forestry etc. are more likely to have an integrated approach towards marketing rather than a mundane one and that's because they aim to typically target a few segments of the customer base. So, they require a particular messaging and product-oriented companies. The 
previ

ous research also claims that IMC can thrive in the businesses and situations where there is an availability of experienced managers and where the markets have a good scope of growth and the intensity of the competition is high. It is believed that messages which are consistent across multiple channels leave an impact on consumer's memory and this memory revives and intensifies upon the exposure to subsequent message through multiple channels that use the same conceptual theme. So, the business having an integrated message will leave a deeper impact on consumer's message than a series of inconsistent messages across different channels. A theory also believes that all aspects of a brand's relation with customer's mind should be taken into account. Both traditional and nontraditional means of promotions should be considered for an effective marketing strategy. (Vanessa A. Tetteh, 2017) One more important concept that has emerged in the IMC umbrella is e-commerce marketing. As per the existing literature, mapping an e- commerce consumer is very important for identifying the consumer segments to be used for targeting advertisements and the placements of these advertisements within the media, it helps in profiling the demographic characteristics of the audience. Determining the media mix and upgrading it with time is one important factor to execute your marketing communications successfully. Researches which have explored the encouragements towards using the ecommerce platform and also the concerns regarding its usage, it includes the factors like trustworthiness of e-tail, adoption of ecommerce and the intention to purchase through ecommerce platforms. (Nicholls, 2005)

\section{Proposed Conceptual Model:}

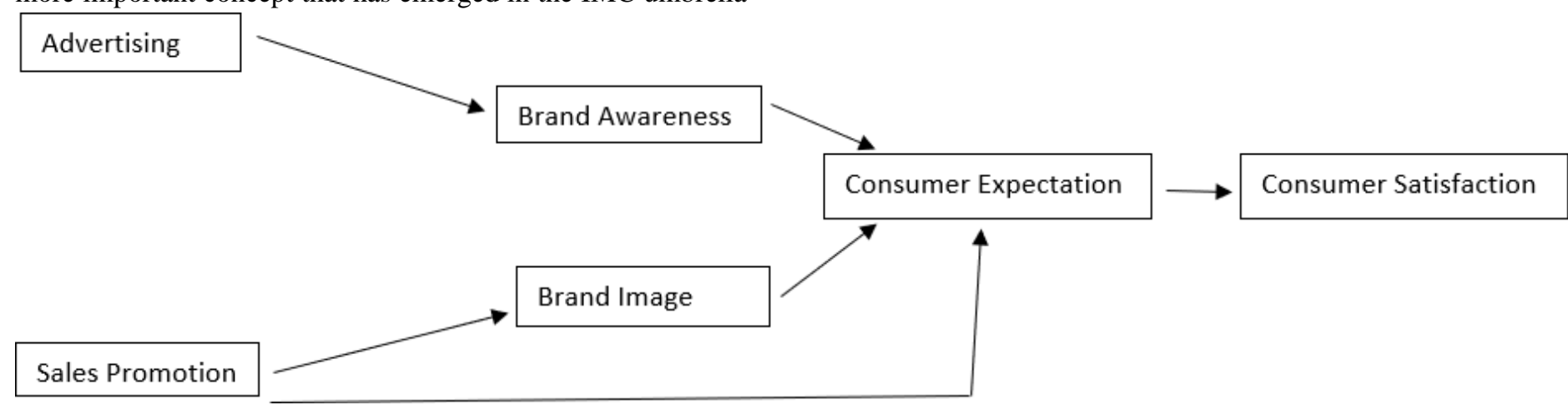

The amalgamation of both; advertising and sales promotion including several other factors make Integrated Marketing Communications a success. While advertising generates a pull effect among the consumers by making them aware about the existence of a particular product or service, the exuberant efforts by the sales team. Right from the relevant communication channels and respective techniques to deal worthy offers, right persuasive techniques, it is the combined effort of both the domains that yields the best outcome for the company. So, the proposed model focuses on demystifying the sales and marketing funnel and understanding it's combined effect by breaking it down into the sub-elements which are the part of advertising and sales promotion tunnels. The subelements are Brand awareness, Brand image, Consumer expectation and Consumer satisfaction are all inter-linked. While advertising helps in generating Brand awareness and forming or maintain the Brand image, the sales promotion helps in creating and fulfilling consumer expectation, and both advertisement and sales promotion collectively determine and fulfil different levels of consumer satisfaction.

\section{DATA AND METHODOLOGY}

Sample size determination:

As per the reports by Morgan Stanley and Live mint, the desired population is found. The target group of the study is people who come across advertisements and communications on various platforms, social media being a major part of the channel clan. So, to find the estimated number of targeted consumers, the focus has been on the number of users of social media platforms where mainly the ads are displayed. The number of users using advertisement friendly apps such as Facebook, Instagram, snapchat, LinkedIn etc. combined come up to average 115300000 people as the total population size. (Source: Google.com)

Thus, as per the sources, there exist 11530000 people as application users out of which on an average $50 \%$ are targeted for advertisements (when not sure of the fix count take the average is $50 \%$ as the population proportion) which makes the desired $\mathrm{p}$ and $\mathrm{q}$ both equal to $\underline{0.5}$.

$\begin{array}{cll}\text { Sample size was calculated with the } & \text { formula: }\end{array}$


EXPECTED SAMPLE SIZE IS: 385.

THE

\section{Dataset:}

To collect the relevant data for carrying out the research study a questionnaire was floated with several questions on various variables. The total responses received are 385 ranging from various states across India. The questionnaire has two sections. The first section of the questionnaire collected the demographic data about the source of advertisement, age group, name, occupation, gender etc. and the second section of the questionnaire asked respondents sub-questions related to four variables Brand awareness, brand image, consumer expectation and consumer satisfaction which come under the umbrella of advertisement and sales promotion.

\section{Methodology:}

Multiple Chi-square tests in SPSS: A chi-square test has been used as a statistical hypothesis test to validate the variables and the acceptance or rejection of null hypothesis on the basis of the results obtained under the test. The reason for choosing Pearson's chi-square was it accurately determines if there is a statistically significant difference between the expected and the observed frequencies in one or more categories of a contingency table. The variables that were taken in the pairs of two to figure out the significance of statistical relationship between them are as follows:

1. Gender and overall satisfaction

2. Occupation and overall satisfaction

3. Sales promotion and overall satisfaction

4. Brand Awareness and Purchase Decision

5. Brand Awareness and Assurance of Quality.

\section{Data Collection Model:}

Primary Data - Primary data means data that are collected by different techniques like questionnaire, Depth interview, Survey, Schedules etc.

For the Analysis, primary data has been collected by the means of questionnaire.

\section{Tools for Analysis}

- $\quad$ IBM SPSS

- $\quad$ MS Excel

Managerial Implications:

- $\quad$ The Research Paper will help the readers to gain knowledge regarding the topic of Integrated Marketing Solutions as well as shall be of help in their academic performance.

- $\quad$ The paper can also help owners of aspirants who own/work at advertising agencies as they would come to know the dynamics and the importance of IMC in today's era.

- $\quad$ The paper shall serve as a reference for the students who shall continue with the research on a similar topic in the future.

\section{DATA ANALYSIS AND FINDINGS Demographic Profile:}

The above table depicts various demographic characteristics of the respondents of the survey conducted. The table mentions each and every category of the types of individuals that were involved in research.

\begin{tabular}{|l|l|}
\hline Gender & 192 \\
\hline Male & 193 \\
\hline Female & \\
\hline Age & 02 \\
\hline 19 - 30 & 378 \\
\hline 31 - 40 & 04 \\
\hline 41 - 50 & 01 \\
\hline Above 50 & 00 \\
\hline Occupation & \\
\hline
\end{tabular}




\section{Analysis:}

\begin{tabular}{|l|l|}
\hline Student & 342 \\
\hline Self-Employed & 12 \\
\hline Employee & 24 \\
\hline Home-Maker & 05 \\
\hline Professional & 01 \\
\hline ther & 01 \\
\hline
\end{tabular}

1. Hypothesis test 1 between Gender and Overall satisfaction and trust over the Integrated Communication:

Ho: Null Hypothesis= The Overall satisfaction and trust over the purchase after witnessing the integrated communication on multiple platforms is independent of gender.

\begin{tabular}{|c|c|c|c|c|c|c|c|c|}
\hline \multicolumn{8}{|c|}{ Overall satisfaction and trust } & \multirow{2}{*}{ Total } \\
\hline Strongly & Disagree & & & & & & Strongly & \\
\hline \multirow[t]{9}{*}{ Gender } & \multirow[t]{6}{*}{ Female } & Count & 1 & 9 & 75 & 95 & 12 & 192 \\
\hline & & $\begin{array}{l}\text { Expected } \\
\text { Count }\end{array}$ & 3.0 & 10.0 & 70.5 & 95.5 & 13.0 & 192.0 \\
\hline & & $\begin{array}{l}\% \quad \text { withi } \\
\text { Gender }\end{array}$ & $\mathrm{n} 0.5 \%$ & $4.7 \%$ & $39.1 \%$ & $49.5 \%$ & $6.3 \%$ & $100.0 \%$ \\
\hline & & $\begin{array}{l}\% \quad \text { withi } \\
\text { Overall } \\
\text { satisfaction an } \\
\text { trust }\end{array}$ & n16.7\% & $45.0 \%$ & $53.2 \%$ & $49.7 \%$ & $46.2 \%$ & $50.0 \%$ \\
\hline & & Residual & -2.0 & -1.0 & 4.5 & -0.5 & -1.0 & \\
\hline & & $\begin{array}{l}\text { Standardized } \\
\text { Residual }\end{array}$ & -1.2 & -0.3 & 0.5 & -0.1 & -0.3 & \\
\hline & \multirow[t]{3}{*}{ Male } & Count & 5 & 11 & 66 & 96 & 14 & 192 \\
\hline & & $\begin{array}{l}\text { Expected } \\
\text { Count }\end{array}$ & 3.0 & 10.0 & 70.5 & 95.5 & 13.0 & 192.0 \\
\hline & & $\begin{array}{l}\% \quad \text { withi } \\
\text { Gender }\end{array}$ & n2.6\% & $5.7 \%$ & $34.4 \%$ & $50.0 \%$ & $7.3 \%$ & $100.0 \%$ \\
\hline
\end{tabular}

Ha: Alternate Hypothesis= The Overall satisfaction and trust over the purchase after witnessing the integrated communication on multiple platforms is dependent on gender.

Gender * Overall satisfaction and trust Crosstabulation 

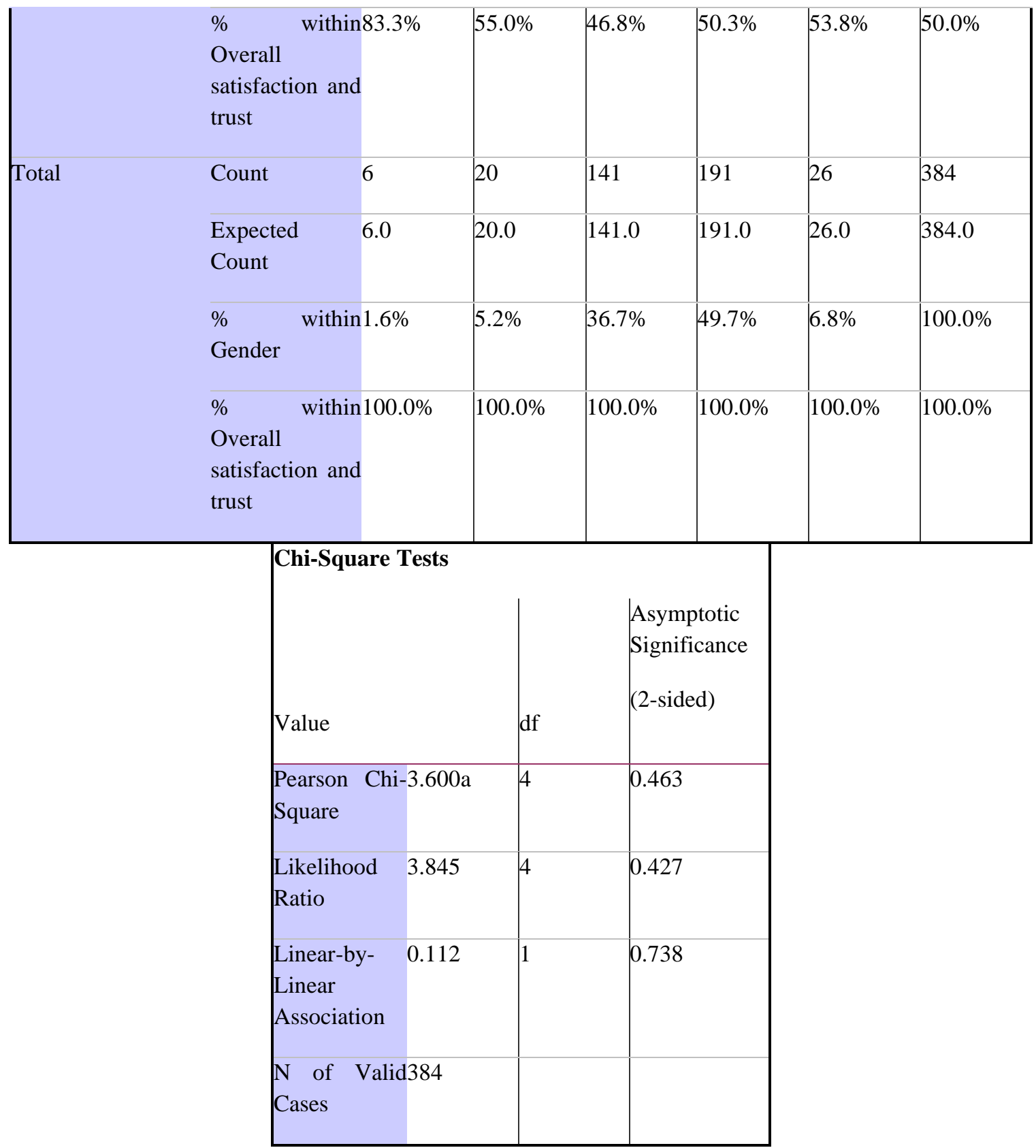

In the first table stated above, we have done a cross tabulation between gender and overall satisfaction and trust. Out of total 384 responses exactly $50 \%$ of them are female and another $50 \%$ respondents are male. When asked if the respondents feel satisfied and assured of trust after making such purchases advertised through integrated marketing, 95 females agreed,
75 of them were neutral, 12 strongly agreed and 9 disagreed while 1 strongly disagreed. Talking about the male respondents, 96 agreed that are assured and satisfied, 66 stood neutral, 14 of them strongly agreed, 11 disagreed and 5 of them strongly disagreed. 


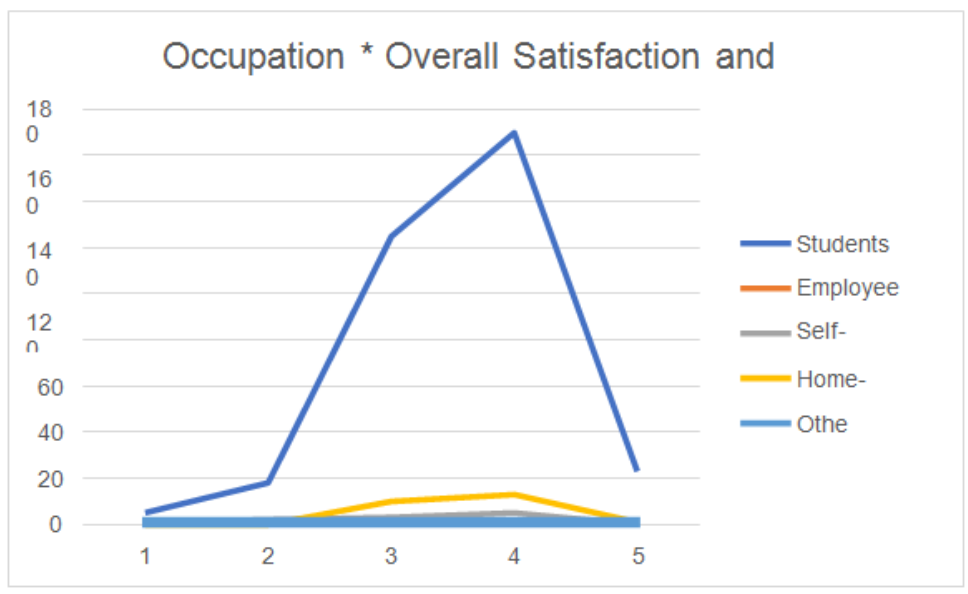

As shown in the graph of the gender satisfaction where the blue line denotes female respondent's satisfaction and the grey line denotes the male respondent's satisfaction and After the outcome of the crosstabulation, the statistical significance between the variables were tested through a chi-square test which gave the Pearson chi-square

value as 0.463 which is greater than 0.05 , which means we accept the Null Hypothesis Ho i.e. The overall satisfaction and assurance of trust on integrated marketing communication is independent of gender.
2. Hypothesis test 2 between Occupation and Overall satisfaction and trust over the Integrated Communication:

Ho: Null Hypothesis = The overall satisfaction and trust over the purchase after witnessing the integrated communication on multiple platforms is independent of occupation.

Ha: Alternate Hypothesis = The overall satisfaction and trust over the purchase after witnessing the integrated communication on multiple platforms is dependent on occupation.

\begin{tabular}{|c|c|c|c|c|c|c|c|c|}
\hline & & & Overall sc & isfaction a & d trust & & & \\
\hline & & & $\begin{array}{l}\text { Strongly } \\
\text { Disagree }\end{array}$ & Disagree & Neutral & Agree & $\begin{array}{l}\text { Strongly } \\
\text { Agree }\end{array}$ & Total \\
\hline Occupation & Student & Count & 5 & 18 & 125 & 170 & 23 & 341 \\
\hline & & $\begin{array}{l}\text { Expected } \\
\text { Count }\end{array}$ & 5.3 & 17.8 & 125.2 & 169.6 & 23.1 & 341.0 \\
\hline & & $\begin{array}{l}\% \text { within } \\
\text { Occupation }\end{array}$ & $1.5 \%$ & $5.3 \%$ & $36.7 \%$ & $49.9 \%$ & $6.7 \%$ & $100.0 \%$ \\
\hline & & $\begin{array}{l}\% \text { within } \\
\text { Overall } \\
\text { satisfaction } \\
\text { and trust }\end{array}$ & $83.3 \%$ & $90.0 \%$ & $88.7 \%$ & $89.0 \%$ & $88.5 \%$ & $88.8 \%$ \\
\hline & & Residual & -0.3 & 0.2 & -0.2 & 0.4 & -0.1 & \\
\hline & & Standardized & -0.1 & 0.1 & 0.0 & 0.0 & 0.0 & \\
\hline
\end{tabular}




\begin{tabular}{|c|c|c|c|c|c|c|c|}
\hline & Residual & & & & & & \\
\hline \multirow{6}{*}{$\begin{array}{l}\text { Self } \\
\text { employed }\end{array}$} & Count & 1 & 2 & 3 & 5 & 0 & 11 \\
\hline & $\begin{array}{l}\text { Expected } \\
\text { Count }\end{array}$ & 0.2 & 0.6 & 4.0 & 5.5 & 0.7 & 11.0 \\
\hline & $\begin{array}{l}\% \text { within } \\
\text { Occupation }\end{array}$ & $9.1 \%$ & $18.2 \%$ & $27.3 \%$ & $45.5 \%$ & $0.0 \%$ & $100.0 \%$ \\
\hline & $\begin{array}{l}\% \text { within } \\
\text { Overall } \\
\text { satisfaction } \\
\text { and trust }\end{array}$ & $16.7 \%$ & $10.0 \%$ & $2.1 \%$ & $2.6 \%$ & $0.0 \%$ & $2.9 \%$ \\
\hline & Residual & 0.8 & 1.4 & -1.0 & -0.5 & -0.7 & \\
\hline & $\begin{array}{l}\text { Standardized } \\
\text { Residual }\end{array}$ & 2.0 & 1.9 & -0.5 & -0.2 & -0.9 & \\
\hline Employee & Count & 0 & 0 & 10 & 13 & 1 & 24 \\
\hline & $\begin{array}{l}\text { Expected } \\
\text { Count }\end{array}$ & 0.4 & 1.3 & 8.8 & 11.9 & 1.6 & 24.0 \\
\hline & $\begin{array}{l}\% \text { within } \\
\text { Occupation }\end{array}$ & $0.0 \%$ & $0.0 \%$ & $41.7 \%$ & $54.2 \%$ & $4.2 \%$ & $100.0 \%$ \\
\hline & $\begin{array}{l}\% \quad \text { within } \\
\text { Overall } \\
\text { satisfaction and } \\
\text { trust }\end{array}$ & $0.0 \%$ & $0.0 \%$ & $7.1 \%$ & $6.8 \%$ & $3.8 \%$ & $6.3 \%$ \\
\hline & Residual & -0.4 & -1.3 & 1.2 & 1.1 & -0.6 & \\
\hline & $\begin{array}{l}\text { Standardized } \\
\text { Residual }\end{array}$ & -0.6 & -1.1 & 0.4 & 0.3 & -0.5 & \\
\hline Home & Count & 0 & 0 & 2 & 1 & 2 & 5 \\
\hline & $\begin{array}{l}\text { Expected } \\
\text { Count }\end{array}$ & 0.1 & 0.3 & 1.8 & 2.5 & 0.3 & 5.0 \\
\hline & $\begin{array}{l}\% \\
\text { Occupation }\end{array}$ & $0.0 \%$ & $0.0 \%$ & $40.0 \%$ & $20.0 \%$ & $40.0 \%$ & $100.0 \%$ \\
\hline
\end{tabular}




\begin{tabular}{|c|c|c|c|c|c|c|c|c|}
\hline & & $\begin{array}{l}\% \text { within } \\
\text { Overall } \\
\text { satisfaction and } \\
\text { trust }\end{array}$ & $0.0 \%$ & $0.0 \%$ & $1.4 \%$ & $0.5 \%$ & $7.7 \%$ & $1.3 \%$ \\
\hline & & Residual & -0.1 & -0.3 & 0.2 & -1.5 & 1.7 & \\
\hline & & $\begin{array}{l}\text { Standardized } \\
\text { Residual }\end{array}$ & -0.3 & -0.5 & 0.1 & -0.9 & 2.9 & \\
\hline & Other & Count & 0 & 0 & 1 & 2 & 0 & 3 \\
\hline & & $\begin{array}{l}\text { Expected } \\
\text { Count }\end{array}$ & 0.0 & 0.2 & 1.1 & 1.5 & 0.2 & 3.0 \\
\hline & & $\begin{array}{l}\% \quad \text { within } \\
\text { Occupation }\end{array}$ & $0.0 \%$ & $0.0 \%$ & $33.3 \%$ & $66.7 \%$ & $0.0 \%$ & $100.0 \%$ \\
\hline & & $\begin{array}{l}\% \quad \text { within } \\
\text { Overall } \\
\text { satisfaction and } \\
\text { trust }\end{array}$ & $0.0 \%$ & $0.0 \%$ & $0.7 \%$ & $1.0 \%$ & $0.0 \%$ & $0.8 \%$ \\
\hline & & Residual & 0.0 & -0.2 & -0.1 & 0.5 & -0.2 & \\
\hline & & $\begin{array}{l}\text { Standardized } \\
\text { Residual }\end{array}$ & -0.2 & -0.4 & -0.1 & 0.4 & -0.5 & \\
\hline \multirow[t]{4}{*}{ Total } & & Count & 6 & 20 & 141 & 191 & 26 & 384 \\
\hline & & $\begin{array}{l}\text { Expected } \\
\text { Count }\end{array}$ & 6.0 & 20.0 & 141.0 & 191.0 & 26.0 & 384.0 \\
\hline & & $\begin{array}{l}\% \quad \text { within } \\
\text { Occupation }\end{array}$ & $1.6 \%$ & $5.2 \%$ & $36.7 \%$ & $49.7 \%$ & $6.8 \%$ & $100.0 \%$ \\
\hline & & $\begin{array}{l}\% \quad \text { within } \\
\text { Overall } \\
\text { satisfaction and } \\
\text { trust }\end{array}$ & $100.0 \%$ & $100.0 \%$ & $100.0 \%$ & $100.0 \%$ & $100.0 \%$ & $100.0 \%$ \\
\hline
\end{tabular}

\begin{tabular}{|l|l|l|l|}
\hline \multicolumn{2}{|l|}{ Chi-Square Tests } & $\begin{array}{l}\text { Asymptotic } \\
\text { Significance } \\
\text { (2-sided) }\end{array}$ \\
\hline & Value & df & \\
\hline $\begin{array}{l}\text { Pearson Chi-20.727a } \\
\text { Square }\end{array}$ & 16 & 0.189 \\
\hline $\begin{array}{l}\text { Likelihood } \\
\text { Ratio }\end{array}$ & 16.240 & 16 & 0.436 \\
\hline
\end{tabular}




\begin{tabular}{|l|l|l|l|}
\hline $\begin{array}{l}\text { Linear-by- } \\
\text { Linear } \\
\text { Association }\end{array}$ & & & \\
\hline $\begin{array}{l}\mathrm{N} \text { of Valid } 384 \\
\text { Cases }\end{array}$ & & & \\
\hline
\end{tabular}

In the tables stated above, we have done a cross tabulation between occupation and overall satisfaction and trust. The category of occupation included occupations like student, selfemployed, employee, home-maker and others. Out of the total 384 respondents, $88.3 \%$ of them were students, $3.1 \%$ of them were self-employed, $6.2 \%$ were employees, $1.3 \%$ were homemaker and $1.1 \%$ were others. Among the 342 respondents who were students, 170 agreed and 23 strongly agreed that they were satisfied and assured of trust while 125 were neutral, 18 disagreed and 5 students strongly disagreed. Among the rest of the occupations, major proportion agreed and strongly agreed while some were neutral.
As shown in the line graph above, most of the respondents have agreed or disagreed in the same proportion among their respective occupation. After the outcome of the crosstabulation, the statistical significance between the variables were tested through

a chi-square test which gave the Pearson chi-square value as 0.189 which is greater than 0.05 , which means we accept the Null Hypothesis Ho i.e. The overall satisfaction and assurance of trust on integrated marketing communication is independent of occupation.

3. Hypothesis test 3 between Effective Sales Promotion and Overall satisfaction and trust over the Integrated Communication:

Ho: Null Hypothesis $=$ The overall satisfaction and assurance of trust over the purchase through marketing communications is independent of effective sales promotion done by the company.

Ha: Alternate Hypothesis $=$ The overall satisfaction and assurance of trust over the purchase through marketing communications is dependent on effective sales promotion done by the company

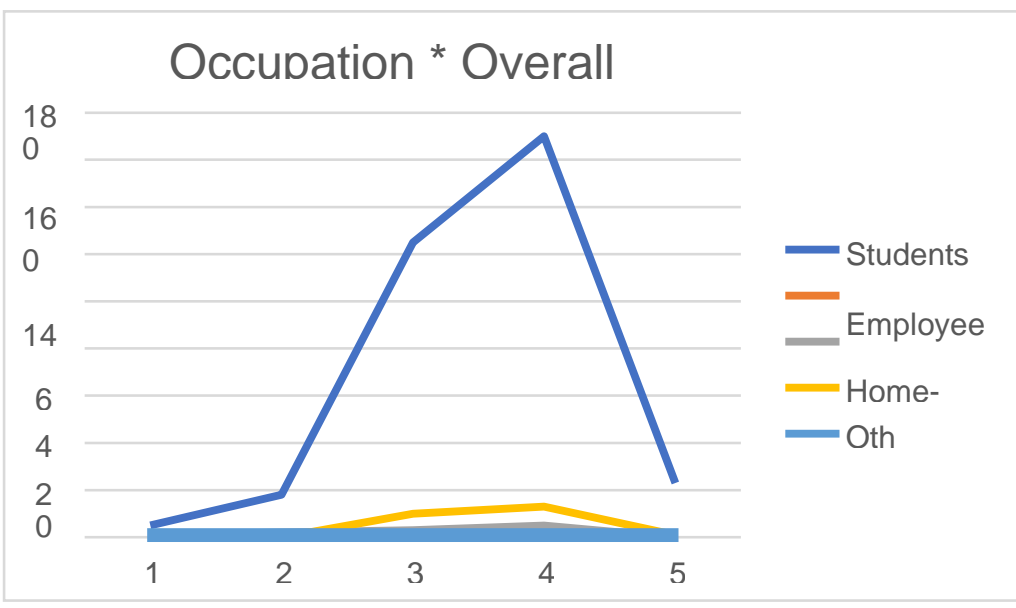

\begin{tabular}{|c|}
\hline Good sales promotion * Overall satisfaction and trust Crosstabu \\
\hline Overall satisfaction and trust \\
\hline
\end{tabular}




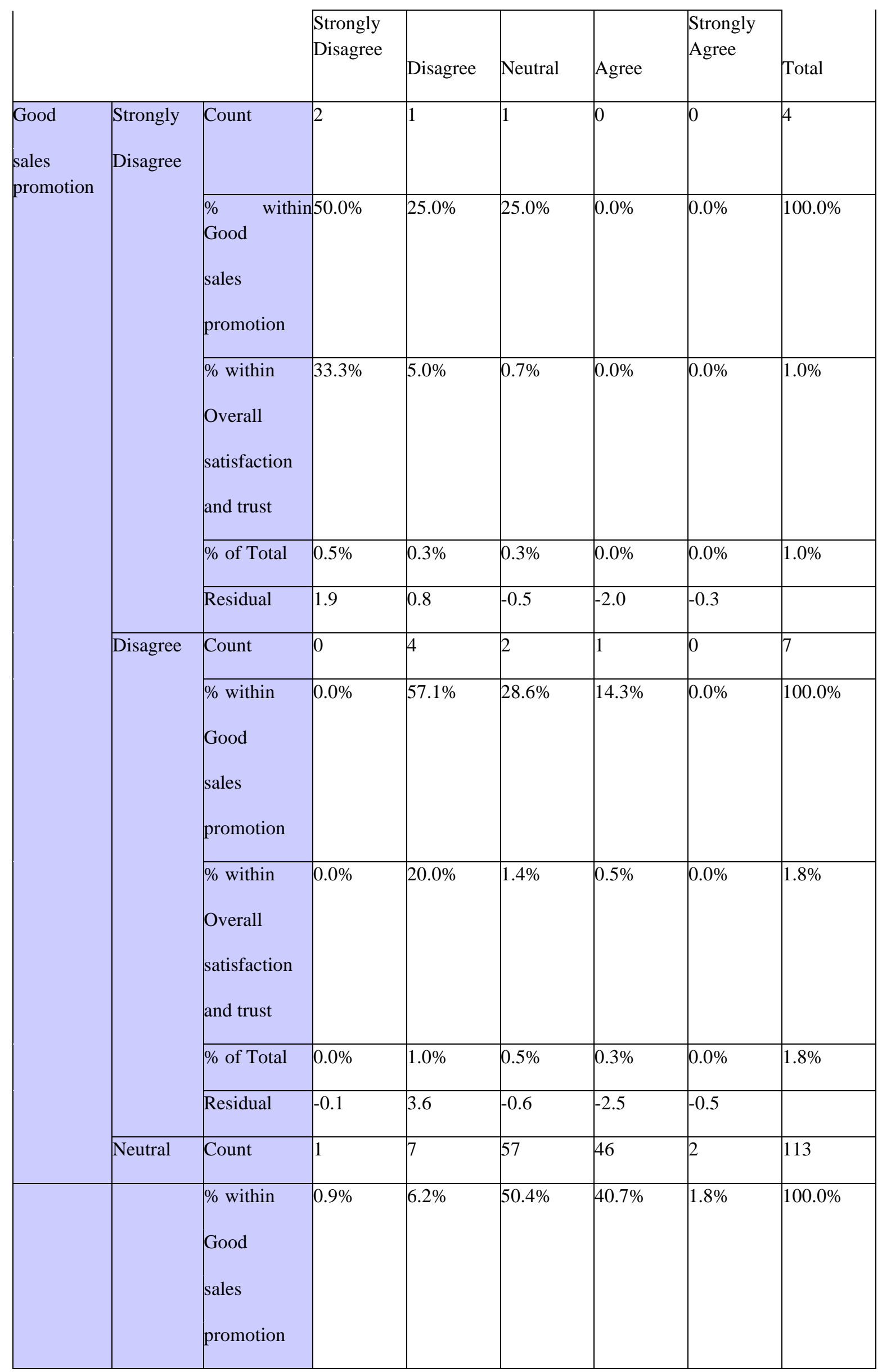




\begin{tabular}{|c|c|c|c|c|c|c|c|}
\hline & $\begin{array}{l}\text { \% within } \\
\text { Overall } \\
\text { satisfaction } \\
\text { and trust }\end{array}$ & $16.7 \%$ & $35.0 \%$ & $40.4 \%$ & $24.1 \%$ & $7.7 \%$ & $29.4 \%$ \\
\hline & $\%$ of Total & $0.3 \%$ & $1.8 \%$ & $14.8 \%$ & $12.0 \%$ & $0.5 \%$ & $29.4 \%$ \\
\hline & Residual & -0.8 & 1.1 & 15.5 & -10.2 & -5.7 & \\
\hline \multirow[t]{5}{*}{ Agree } & Count & 3 & 8 & 72 & 129 & 17 & 229 \\
\hline & $\begin{array}{l}\text { \% within } \\
\text { Good } \\
\text { sales } \\
\text { promotion }\end{array}$ & $1.3 \%$ & $3.5 \%$ & $31.4 \%$ & $56.3 \%$ & $7.4 \%$ & $100.0 \%$ \\
\hline & $\begin{array}{l}\% \text { within } \\
\text { Overall } \\
\text { satisfaction } \\
\text { and trust }\end{array}$ & $50.0 \%$ & $40.0 \%$ & $51.1 \%$ & $67.5 \%$ & $65.4 \%$ & $59.6 \%$ \\
\hline & $\%$ of Total & $0.8 \%$ & $2.1 \%$ & $18.8 \%$ & $33.6 \%$ & $4.4 \%$ & $59.6 \%$ \\
\hline & Residual & -0.6 & -3.9 & -12.1 & 15.1 & 1.5 & \\
\hline \multirow[t]{5}{*}{$\begin{array}{l}\text { Strongly } \\
\text { Agree }\end{array}$} & Count & 0 & 0 & 9 & 15 & 7 & 31 \\
\hline & $\begin{array}{l}\text { \% within } \\
\text { Good } \\
\text { sales } \\
\text { promotion }\end{array}$ & $0.0 \%$ & $0.0 \%$ & $29.0 \%$ & $48.4 \%$ & $22.6 \%$ & $100.0 \%$ \\
\hline & $\begin{array}{l}\text { \% within } \\
\text { Overall } \\
\text { satisfaction } \\
\text { and trust }\end{array}$ & $0.0 \%$ & $0.0 \%$ & $6.4 \%$ & $7.9 \%$ & $26.9 \%$ & $8.1 \%$ \\
\hline & $\%$ of Total & $0.0 \%$ & $0.0 \%$ & $2.3 \%$ & $3.9 \%$ & $1.8 \%$ & $8.1 \%$ \\
\hline & Residual & -0.5 & -1.6 & -2.4 & -0.4 & 4.9 & \\
\hline
\end{tabular}




\begin{tabular}{|c|c|c|c|c|c|c|c|}
\hline \multirow[t]{4}{*}{ Total } & Count & 6 & 20 & 141 & 191 & 26 & 384 \\
\hline & $\begin{array}{l}\% \text { within } \\
\text { Good } \\
\text { sales } \\
\text { promotion }\end{array}$ & $1.6 \%$ & $5.2 \%$ & $36.7 \%$ & $49.7 \%$ & $6.8 \%$ & $100.0 \%$ \\
\hline & $\begin{array}{l}\% \text { within } \\
\text { Overall } \\
\text { satisfaction } \\
\text { and trust }\end{array}$ & $100.0 \%$ & $100.0 \%$ & $100.0 \%$ & $100.0 \%$ & $100.0 \%$ & $100.0 \%$ \\
\hline & $\%$ of Total & $1.6 \%$ & $5.2 \%$ & $36.7 \%$ & $49.7 \%$ & $6.8 \%$ & $100.0 \%$ \\
\hline
\end{tabular}

\begin{tabular}{|c|c|c|c|}
\hline \multicolumn{4}{|c|}{ Chi-Square Tests } \\
\hline & Value & df & $\begin{array}{l}\text { Asymptotic } \\
\text { Significance } \\
(2 \text {-sided) }\end{array}$ \\
\hline $\begin{array}{l}\text { Pearson Chi- } \\
\text { Square }\end{array}$ & $135.898 \mathrm{a}$ & 16 & 0.000 \\
\hline $\begin{array}{l}\text { Likelihood } \\
\text { Ratio }\end{array}$ & 62.840 & 16 & 0.000 \\
\hline $\begin{array}{l}\text { Linear-by- } \\
\text { Linear } \\
\text { Association }\end{array}$ & 45.151 & 1 & 0.000 \\
\hline $\begin{array}{ll}\mathrm{N} \text { of } & \text { Valid } \\
\text { Cases } & \end{array}$ & 384 & & \\
\hline
\end{tabular}

Sales promotion and advertising are two crucial elements on which the model of Integrated marketing communications is based on. So, to validate the same the hypothesis test 3 focuses on finding the significance between the effective sales promotion and Overall satisfaction and assurance of trust among the customers.

In the cross tabulation between the two variables, 229 respondents have agreed that sales promotion encourages their purchase decision and acts as a catalyst after watching the communications. 31 respondents strongly agreed to the same while 113 respondents remained neutral and a very less proportion of the lot i.e. 7 respondents disagreed while 4 strongly disagreed. The effect of sales promotion is described in the bar chart below where 1 denotes strongly disagree and 5 denotes strongly agree.

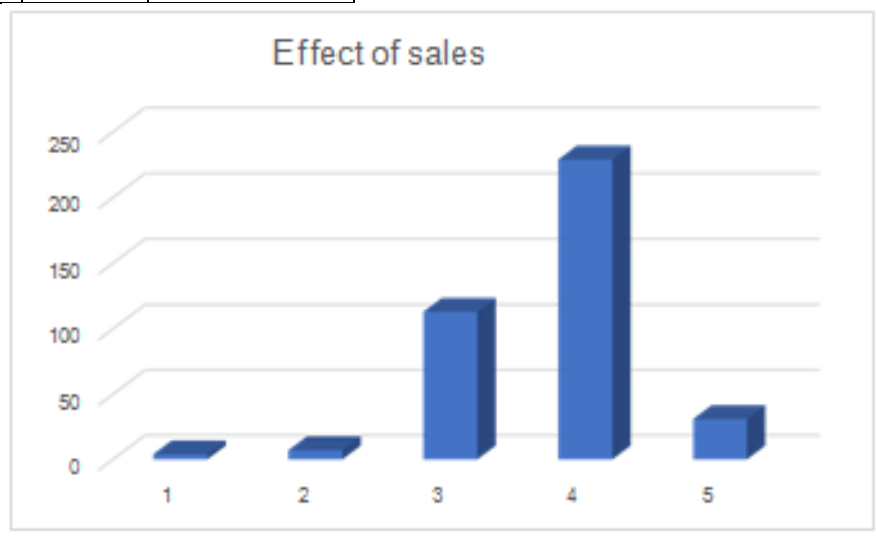

As the bar chart above states, majority of people have agreed and strongly agreed that effective sales promotion plays a very important part in their purchase and repurchase decision, with 
Pearson Chi-Square value being 0.00 which is less than

0.05 which implies that we reject the null hypothesis Ho and accept the Alternate

Hypothesis Ha which proves that Effective sales promotion has a significant role to play in assuring the trust and satisfaction to customers.
4. Hypothesis test 4 between Brand Awareness and satisfaction with the purchase decision:

Ho: Null Hypothesis $=$ The satisfaction with the purchase decision is independent on Awareness of offers showcased by multiple media communications.

Ha: Alternate Hypothesis $=$ The satisfaction with the purchase decision is dependent on Awareness of offers showcased by multiple media communications.

\begin{tabular}{|c|c|c|c|c|c|c|c|}
\hline \multicolumn{8}{|c|}{ Awareness of offers * Happy about the purchase decision Crosstabulation } \\
\hline & & \multicolumn{5}{|c|}{ Happy about the purchase decision } & \multirow[b]{2}{*}{ Total } \\
\hline & & $\begin{array}{l}\text { Strongly } \\
\text { Disagree }\end{array}$ & Disagree & Neutral & Agree & $\begin{array}{l}\text { Strongly } \\
\text { Agree }\end{array}$ & \\
\hline \multirow{5}{*}{$\begin{array}{l}\text { Awareness of Strongly } \\
\text { offers }\end{array}$} & Count & 1 & 2 & 2 & 0 & 1 & 6 \\
\hline & $\begin{array}{l}\% \text { within } \\
\text { Awareness of } \\
\text { offers }\end{array}$ & $16.7 \%$ & $33.3 \%$ & $33.3 \%$ & $0.0 \%$ & $16.7 \%$ & $100.0 \%$ \\
\hline & $\begin{array}{ll}\% & \text { within } \\
\text { Happy } & \text { about } \\
\text { the } & \text { purchase } \\
\text { decision }\end{array}$ & $14.3 \%$ & $5.9 \%$ & $1.4 \%$ & $0.0 \%$ & $3.1 \%$ & $1.6 \%$ \\
\hline & $\%$ of Total & $0.3 \%$ & $0.5 \%$ & $0.5 \%$ & $0.0 \%$ & $0.3 \%$ & $1.6 \%$ \\
\hline & Residual & 0.9 & 1.5 & -0.2 & -2.6 & 0.5 & \\
\hline \multirow[t]{5}{*}{ Disagree } & Count & 0 & 2 & 3 & 5 & 0 & 10 \\
\hline & $\begin{array}{ll}\% & \text { within } \\
\text { Awareness of } \\
\text { offers }\end{array}$ & $0.0 \%$ & $20.0 \%$ & $30.0 \%$ & $50.0 \%$ & $0.0 \%$ & $100.0 \%$ \\
\hline & $\begin{array}{ll}\% & \text { within } \\
\text { Happy } & \text { about } \\
\text { the } & \text { purchase } \\
\text { decision }\end{array}$ & $0.0 \%$ & $5.9 \%$ & $2.1 \%$ & $3.0 \%$ & $0.0 \%$ & $2.6 \%$ \\
\hline & $\%$ of Total & $0.0 \%$ & $0.5 \%$ & $0.8 \%$ & $1.3 \%$ & $0.0 \%$ & $2.6 \%$ \\
\hline & Residual & -0.2 & 1.1 & -0.7 & 0.6 & -0.8 & \\
\hline \multirow[t]{2}{*}{ Neutral } & Count & 3 & 3 & 16 & 8 & 1 & 31 \\
\hline & $\begin{array}{l}\% \text { within } \\
\text { Awareness of } \\
\text { offers }\end{array}$ & $9.7 \%$ & $9.7 \%$ & $51.6 \%$ & $25.8 \%$ & $3.2 \%$ & $100.0 \%$ \\
\hline
\end{tabular}




\begin{tabular}{|c|c|c|c|c|c|c|c|c|}
\hline & & $\begin{array}{l}\% \\
\text { Happy about } \\
\text { the purchase } \\
\text { decision }\end{array}$ & $42.9 \%$ & $8.8 \%$ & $11.2 \%$ & $4.8 \%$ & $3.1 \%$ & $8.1 \%$ \\
\hline & & $\%$ of Total & $0.8 \%$ & $0.8 \%$ & $4.2 \%$ & $2.1 \%$ & $0.3 \%$ & $8.1 \%$ \\
\hline & & Residual & 2.4 & 0.2 & 4.4 & -5.5 & -1.6 & \\
\hline & Agree & Count & 2 & 20 & 75 & 104 & 6 & 207 \\
\hline & & $\begin{array}{l}\% \text { within } \\
\text { Awareness of } \\
\text { offers }\end{array}$ & $1.0 \%$ & $9.7 \%$ & $36.2 \%$ & $50.2 \%$ & $2.9 \%$ & $100.0 \%$ \\
\hline & & $\begin{array}{l}\% \text { within } \\
\text { Happy about } \\
\text { the purchase } \\
\text { decision }\end{array}$ & $28.6 \%$ & $58.8 \%$ & $52.4 \%$ & $62.3 \%$ & $18.8 \%$ & $54.0 \%$ \\
\hline & & $\%$ of Total & $0.5 \%$ & $5.2 \%$ & $19.6 \%$ & $27.2 \%$ & $1.6 \%$ & $54.0 \%$ \\
\hline & & Residual & -1.8 & 1.6 & -2.3 & 13.7 & -11.3 & \\
\hline & Strongly & Count & 1 & 7 & 47 & 50 & 24 & 129 \\
\hline & & $\begin{array}{l}\% \text { within } \\
\text { Awareness of } \\
\text { offers }\end{array}$ & $0.8 \%$ & $5.4 \%$ & $36.4 \%$ & $38.8 \%$ & $18.6 \%$ & $100.0 \%$ \\
\hline & & $\begin{array}{l}\% \text { within } \\
\text { Happy about } \\
\text { the purchase } \\
\text { decision }\end{array}$ & $14.3 \%$ & $20.6 \%$ & $32.9 \%$ & $29.9 \%$ & $75.0 \%$ & $33.7 \%$ \\
\hline & & $\%$ of Total & $0.3 \%$ & $1.8 \%$ & $12.3 \%$ & $13.1 \%$ & $6.3 \%$ & $33.7 \%$ \\
\hline & & Residual & -1.4 & -4.5 & -1.2 & -6.2 & 13.2 & \\
\hline Total & & Count & 7 & 34 & 143 & 167 & 32 & 383 \\
\hline & & $\begin{array}{l}\% \text { within } \\
\text { Awareness of } \\
\text { offers }\end{array}$ & $1.8 \%$ & $8.9 \%$ & $37.3 \%$ & $43.6 \%$ & $8.4 \%$ & $100.0 \%$ \\
\hline & & $\begin{array}{l}\% \\
\text { Happy about } \\
\text { the purchase } \\
\text { decision }\end{array}$ & $100.0 \%$ & $100.0 \%$ & $100.0 \%$ & $100.0 \%$ & $100.0 \%$ & $100.0 \%$ \\
\hline & & $\%$ of Total & $1.8 \%$ & $8.9 \%$ & $37.3 \%$ & $43.6 \%$ & $8.4 \%$ & $100.0 \%$ \\
\hline
\end{tabular}

\section{Chi-Square Tests}




\begin{tabular}{|l|l|l|l|}
\hline & & & Asymptotic \\
& Value & df & $\begin{array}{l}\text { Significance } \\
\text { (2-sided) }\end{array}$ \\
\hline $\begin{array}{l}\text { Pearson Chi-62.428a } \\
\text { Square }\end{array}$ & 16 & 0.000 \\
\hline $\begin{array}{l}\text { Likelihood } \\
\text { Ratio }\end{array}$ & 53.378 & 16 & 0.000 \\
\hline $\begin{array}{l}\text { Linear-by- } \\
\text { Linear } \\
\text { Association }\end{array}$ & 20.395 & 1 & 0.000 \\
\hline $\begin{array}{l}\text { N of Valid } 383 \\
\text { Cases }\end{array}$ & & & \\
\hline
\end{tabular}

Integrated strategy for communicating through multiple channels is majorly used for creating awareness regarding the brand, its offers, sale etc. So, to validate the same, hypothesis test 4 aims at identifying the statistical significance between the two variables to identify if there the purchase decision is dependent of this awareness generation or not.

In the cross tabulation between the two variables, 207 respondents have agreed that Brand Awareness encourages their purchase decision and acts as a catalyst after watching the communications. 129 respondents strongly agreed to the same while 31 respondents remained neutral and a very less proportion of the lot i.e. 10 respondents disagreed while 6 strongly disagreed.

As majority of people have agreed and strongly agreed that effective brand awareness plays a very important part in their purchase and repurchase decision, with the Pearson ChiSquare value being 0.00 which is less than 0.05 which implies that we reject the null hypothesis Ho and accept the Alternate Hypothesis Ha which proves that Brand Awareness has a significant role to play in assuring the trust when they are making their purchase decisions.

\section{LIMITATIONS OF THE STUDY}

- Time Factor- the study has been completed in a limited time which may not justify the actual study.

- The Research covers a survey of only 385 respondents. Hence, we admit that sample size is very small as compared to the total population.

- The demographic of the audience majorly constitutes the age group of $18-30$ and hence it does not cover all the age groups in its inclusivity.

- The shift in pattern that we determine may not last long and everything can be back to how it was before the outbreak.

\section{RECOMMENDATIONS/SCOPE RESEARCH}

Future research could be conducted using a larger sample size. Further, the research can be conducted on a wider scale including varied demographics and expert opinions of marketers and advertisers along with consumers. Moreover, consumers' perception towards different marketing and promotional schemes could be taken as a step further by noticing their preferences for different products on the basis of different sales and marketing promotion schemes.

\section{CONCLUSIONS}

The era of marketing has been evolving and so is the competition. Marketers are continuously finding various methods to make their advertisements attractive. One such method is Integrated Marketing Communications, whose knowledge and awareness had been realized into this study.

The objective of checking the efficacy on the various facets of Integrated Communications in the Indian businesses had been realized in the aspect that people are aware about this kind of marketing; they notice such type of advertisements from various platforms and it definitely influences their decision whether it's during making a purchase or after it.

The objective of determining the shift in pattern towards the use of multiple platforms against one in past had been justified in the aspect that most of our respondents are keen to integrated communications in their daily life and it definitely impacts their behavior as a consumer.

People find that sometimes these advertisements do influence the buying habit and purchase behavior however, effective sales promotion also contributes a lot to the buying habit along with advertisements. The combination of two helps creating brand awareness 
also helps in assuring trust to its consumers.

The age group of 18 to 30 is more likely to be impacted and influenced by the mix media strategy as the population in that age bracket is exposed to a lot of content and is more active on most of the platforms.

The emergence of online shopping as a consumer habit has increased the scope and purpose of these communications through multiple mediums as many people are now comfortable staying in their homes (This may change once the situation gets back to normal)

The communication from each medium plays an equally important role as most of the respondents chose almost all the platforms right from billboards to digital media when asked which platforms do they come across when they see Advertisements.

All in all, one message spread across multiple platforms reaches wider audience, creates a strong recall and influences the buyer behavior positively and assures trust and awareness among the consumers.

\section{REFERENCES}

Bibliography

[1]. Lake, L. (2019, May 31). About Integrated Marketing Communications. Retrieved from The balance small business https://www.thebalancesmb.com/integratedmarketing-communication-imc-2295501

[2]. Linton, I. (2019, February 12). Chron. Retrieved from smallbusiness.chron.com: https://smallbusiness.chron.com/importanceintegrated-marketing-communications- 73248.html

[3]. Mulchandji Sen, D. J. (2017). Use and Preferences of Promotional Tools by Small and Micro Business Organizations in South Gujarat Region, India. International Journal of Engineering Technology Science and Research, 7.

[4]. Nicholls, K. S. (2005). Media Mix Elements that Motivate Online Shopping. Journal of website promotion, 12.

[5]. Percy, J. r. (2012). How the roles of advertising merely appear to have changed. ICORIA, 9.

[6]. Quach, P. T. (2016). Integrated Marketing Communications and Their Effects on Customer Switching Intention. JOURNAL OF RELATIONSHIP MARKETING, 17.
[7]. Rubtcova, O. P. (2019). Development of the Concept 'integrated Marketing Communications'. SSRN, 9. Telrandhe, D. S. (2010). ROLE OF INTEGRATED MARKETING COMMUNICATION IN MODERN INDIAN

[8]. BUSINESS. Researchers World - Journal of Arts Science and Commerce, 5.

[9]. Vanessa A. Tetteh, P. (2017). Future of Integrated Marketing Communications. EBSCO research starters, 10 . 